\title{
Subsurface Evapotranspiration Irrigation System Design in System of Rice Intensification (SRI) Salibu Paddy Cultivation
}

\author{
${ }^{1}$ Department of Mechanical and Biosystem Engineering, IPB University \\ Bogor, Indonesia \\ Email: hildaagustina [AT] fp.unsri.ac.id \\ ${ }^{2}$ Department of Agricultural Engineering, Sriwijaya University \\ Palembang, Indonesia \\ Email: hildaagustina [AT] fp.unsri.ac.id \\ ${ }^{3}$ Department of Civil and Environmental Engineering, IPB University \\ Bogor, Indonesia \\ Email: budindra [AT] apps.ipb.ac.id \\ ${ }^{4}$ Department of Agronomy, IPB University \\ Bogor, Indonesia \\ Email: sugiyanta [AT] apps.ipb.ac.id \\ ${ }^{5}$ Department of Mechanical and Biosystem Engineering, IPB University \\ Bogor, Indonesia \\ Email: msoul9 [AT] yahoo.com \\ ${ }^{6}$ Department of Civil Engineering, State University of Malang \\ Malang, Indonesia \\ Email: vita.ayu.kusuma.ft [AT] um.ac.id
}

Hilda Agustina ${ }^{1,2}$, Budi Indra Setiawan ${ }^{3}$, Sugiyanta $^{4}$, Mohamad Solahudin $^{5}$, and Vita Ayu Kusuma Dewi ${ }^{6}$

\begin{abstract}
The System of Rice Intensification (SRI), a water-saving paddy cultivation system, has been implemented in Indonesia. The application of SRI can increase water productivity. The Salibu method applied to paddy cultivation can save seeds, costs, labour and increase the planting index of paddy. However, when used in other areas, the yield is reduced by up to 50 per cent from the first harvest. A combination of cultivation and water management is needed to save water and increase paddy production. The method used in this research is experimental research. The design of the irrigation system was made according to the technical design, then tested for automatic water management. The design was tested with the SRI Salibu method. The data are climate data, water level, water discharge, and water content. The climate data used are temperature and solar radiation to determine potential evapotranspiration. The results of observations of water depth, the volume of water in the system, the water content in the media, water entering the system (rain infiltration, irrigation discharge), and water leaving the system (runoff, discharge) are entered into the water balance equation (water balance). The plant coefficient value is included in the water balance equation as a plant coefficient factor multiplied by the potential evapotranspiration value. Then the plant coefficient value for each observation is optimized by reducing the error value to get the coefficient value for SRI Salibu. The results showed that the appropriate evapotranspiration irrigation system for SRI Salibu paddy cultivation is the fifth irrigation system design. The fifth irrigation system design can produce 4.7 tons/ha of paddy (SRI method) and produce SRI Salibu paddy yields of 8 tons/ha. The irrigation water for SRI paddy cultivation is 1738 litres, and the water production is $1.2 \mathrm{~kg} / \mathrm{m}^{3}$.
\end{abstract}

Keywords - Evapotranspiration irrigation system, SRI Salibu, Paddy cultivation

\section{INTRODUCTION}

Population growth causes food needs to increase [4]. An increase in population and economy cause land-use change. This causes the land to support food cultivation activities is decreasing. Rice production is strongly influenced by water availability in the cultivation area [6]. The provision of irrigation water will affect the growth of paddy plants during the generative period [8]. 
The ratoon technology was further developed into Salibu, increasing paddy harvest production by more than $100 \%$ from the first season harvest to increase farmers' income, especially in Tabek village, West Sumatra [5]. However, after being tested in other areas, the production decreased by around 50\% from the first planting season. There was no interaction between the cutting height of the paddy stump with the planting method on the yield [9]. Applications with SRI save water by keeping the soil moist, not constantly flooded, saving water use $[2,13]$. This combination of cultivation will produce a new technology with an intelligent irrigation system for SRI Salibu paddy cultivation. The subsurface evapotranspiration irrigation system is a prototype of water management technology that will support the success of SRI Salibu paddy cultivation in increasing production, especially in Indonesia.

This research aims to design an irrigation system that is automatic, practical, can be applied to marginal land conditions with optimal results and can support the availability of water for cultivated plants, especially SRI Salibu paddy plants.

\section{MATERIALS AND METHODS}

This research was conducted from July 2018 to June 2021. The method used in this study is experimental. The tools used are data logger ECH2O (EM50), 5TE sensor (volumetric water content, electrical conductivity, temperature), (Decagon PYR Pyranometer sensor), humidity and temperature (Decagon VP-4 sensor), rainfall (ECRN100 Highresolution rain gauge) and CTD (Conductivity/Temperature/Depth sensor) sensors. Irrigation and drainage water discharges were recorded using a water meter type LD 410 (SNI 2547 (2008) (liters/day)). Electric oven, a tool used to determine the moisture content of materials (soil and crop yields), 18 mesh size soil sieve, analytical balance. caliper, 10 Mpix digital camera, fertility of paddy fields, water meter (liter), auger hole, straight stop faucet. Stop faucet (size in, $3 / 4$ in), stop valve type float (ball valve) size in for high pressure (can work at pressure 0.02-1.0 MPA), because the water source comes from a reservoir that has high pressure. Paddy field soil fertility tester (PUTS) and its accessories to measure soil fertility and soil $\mathrm{pH}$ regularly. Workshop tools, consisting of hacksaws, grinders, electric drills, chisels, screwdrivers, clamping pliers.

The materials used include drill bits (pipe hole drill bits), grinders, angled iron $(3 \mathrm{~mm})$, electric welding equipment, pipe insulation. Pot (specification top diameter $46.3 \mathrm{~cm}$, bottom diameter $37 \mathrm{~cm}$, height $38.5 \mathrm{~cm}$ ), water bath $(46.3 \mathrm{~cm}$ diameter and $30 \mathrm{~cm}$ high). PVC pipe (size in, this, $1 \mathrm{in}$ ), pipe joints (T, elbow, straight, dope) with the same size as the pipe, pipe glue, Araldite brand plastic glue, paddy seeds of Batang Piaman and Inpari 42 varieties, IPB 3S, manure, EM4, Hormax organic fertilizer, inorganic fertilizer (Urea, TSP, $\mathrm{KCl}, \mathrm{NaCl}$ ), organic and inorganic pesticides. The research procedure can be seen in Figure 1. The first irrigation system design is sub-surface. Water enters through the float stop valve so that irrigation water can enter the system automatically.

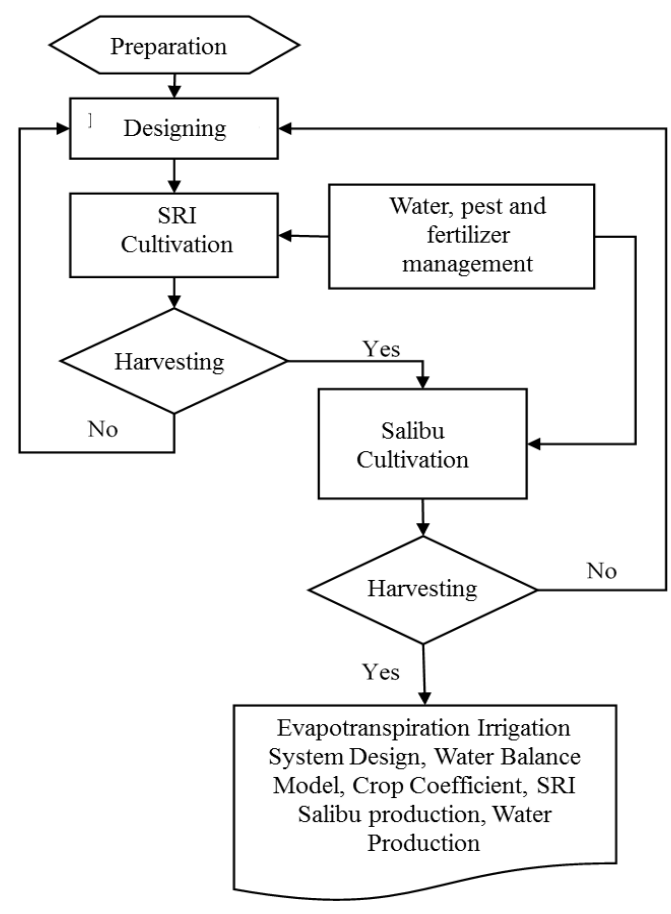

Figure 1: Field test procedure of subsurface evapotranspiration irrigation system in SRI and Salibu paddy cultivation 
The SRI cultivation method follows the SRI cultivation implementation procedure [14]. The Salibu paddy cultivation method follows the procedure for implementing Salibu paddy cultivation [1]. The water management used in this study is in accordance with the application of standing water in the SRI cultivation application which has been tested by Hasanah [7].

\section{RESULTS AND DISCUSSION}

Design testing of the evapotranspiration irrigation system can be seen in Figure 2 . (a) The first test (D1, subsurface flow irrigation system), (D2, evaporation irrigation system (drip)) outside the greenhouse. (b) the second test (D3, evapotranspiration irrigation system, in the greenhouse, manual irrigation, and drainage. (c) the third test (D4, evapotranspiration irrigation system, outside the greenhouse, manual irrigation, and drainage. (d) The fourth test (D5, design of automatic evapotranspiration irrigation system, modification of potting media layer, fixed water level), (D6, modification of pot without pot tub).

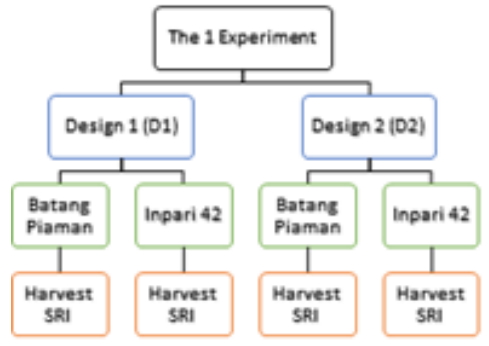

(a)

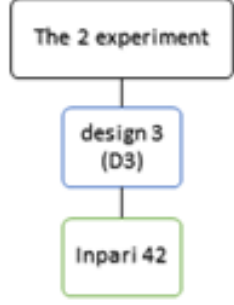

(b)

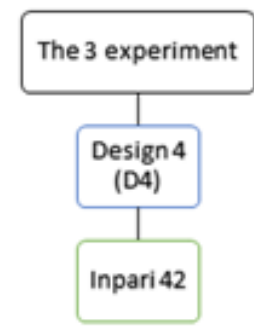

(c)

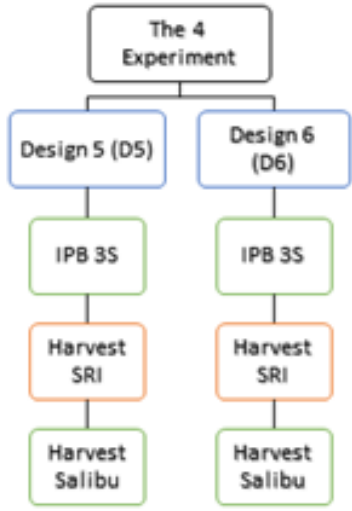

(d)

Figure 2 : Each irrigation system testing activity in the field

In the first irrigation system design (D1) (Figure 3), water enters the system from rainwater and irrigation water (incoming from 2 inlet pipes). This irrigation water is regulated by a stop faucet ball valve type that has been set according to the water level in the 2 reservoirs (left and right) of the row of pots. Runoff water when it rains comes out of the pot through the $\mathrm{T}$ pipe which has been set to the optimum height $(0 \mathrm{~cm}$ above the ground) (according to the SRI method treatment). 


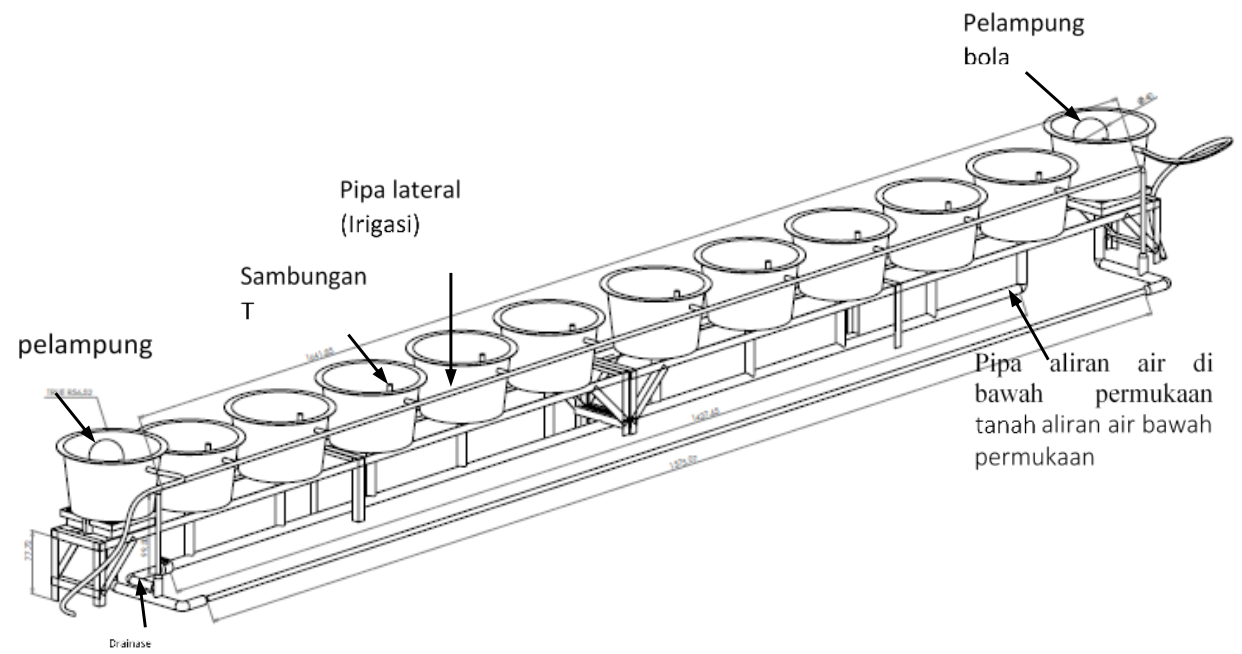

Figure 3: The first irrigation system design (D1)

The Second irrigation system design (D2) (Figure 4) can only produce crops in SRI paddy cultivation. When preparing for Salibu paddy cultivation, (following the procedure for implementing Salibu paddy cultivation [1] paddy died at 2 weeks after planting (both in irrigation system designs 1 and 2). The first and second designs could not be continued for the cultivation of Salibu paddy.

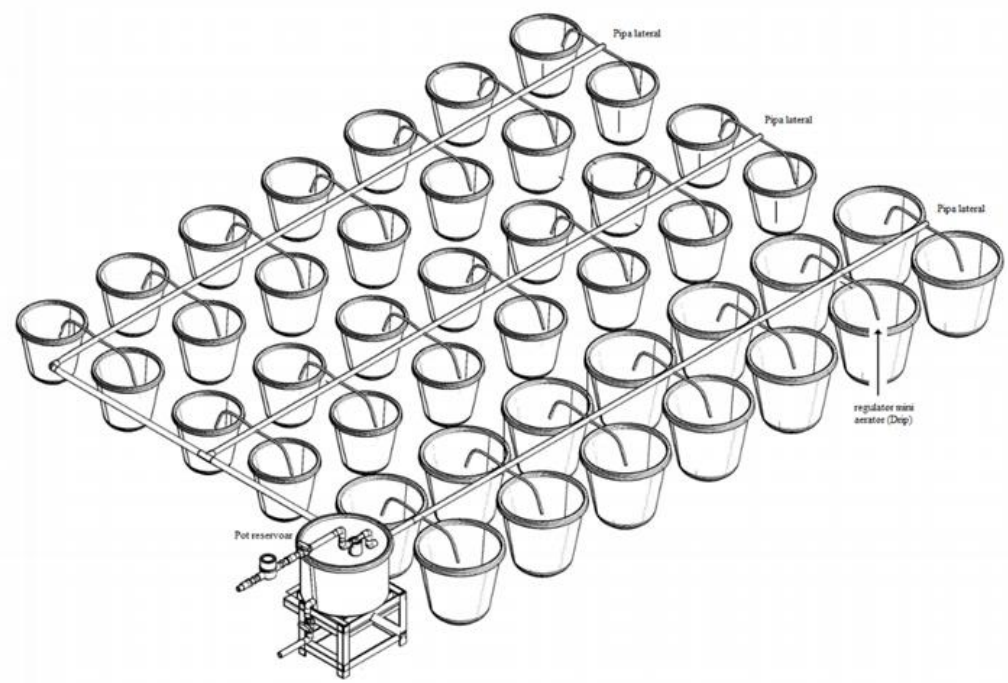

Figure 4: The second irrigation system design (D2)

During the generative period, rain is more frequent, so the dry grain yield of the SRI method in the D2 design is higher than the D1 design. In the D1 design, the potential for dry grain harvest of the Inpari 42 variety was 8900.5 $\mathrm{kg} / \mathrm{ha}$ /season, while in D2, it was $9392.4 \mathrm{~kg} / \mathrm{ha} / \mathrm{season}$. In the Batang Piaman variety, the potential for dry grain harvesting using the SRI method at D1 was $7540.6 \mathrm{~kg} / \mathrm{ha} / \mathrm{season}$ and at D2 was $8477.4 \mathrm{~kg} / \mathrm{ha} / \mathrm{season}$. The provision of irrigation water with irrigation and drainage arrangements according to the needs of aquatic plants per phase will provide air circulation and oxygen suitable for plant growth $[10,11]$. Good aeration conditions and increased soil temperature conditions will increase the permeability of root cells, thereby increasing the absorption of nutrients by plants [12] 


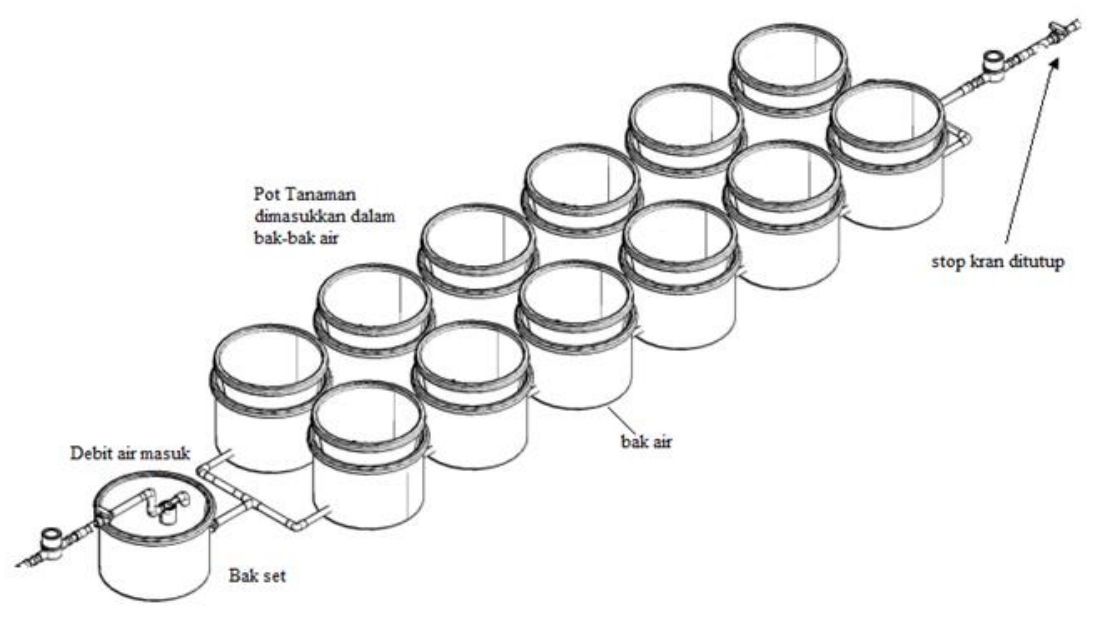

Figure 5: The third irrigation system design (D3)

Then the test was continued with the design of the third irrigation system (D3) Figure 5. In the third design, the first planting season was SRI paddy cultivation. Paddy plants experienced stress from 2 days of transplanting. The growth of paddy plants was thin, stunted, the longer the dries up, and in the end, the paddy plants die. Then the irrigation system design was changed to the fourth irrigation system design (D4) and tested outside the greenhouse. This system was made similar to the first system design so that this system, irrigation, and drainage were still done manually (opening and closing) valve on the stop faucet. This causes the system not be able to provide water that meets the needs of the paddy plant. Paddy plants will eventually die due to stress at the beginning of the growth phase. The design of the irrigation system was continued by adding a pipe set (which regulates the water level at the end of the system (in the fifth and sixth designs).



Figure 6: The fourth irrigation system design (D4)

The design of the fifth irrigation system (D5)is the same as the design of the sixth irrigation system (D6). The difference between these two systems is in the plant pots. The plant pots in the fifth design are separated from pots, while in the sixth design, there are no pots. As a result of the sixth design, there are many obstacles in the form of disruption of water flow in the system due to clogged soil particles that escape the filter cloth. Design of irrigation systems the fifth one must be cleaned more often of this blockage by opening the pipe connection, especially at the set pipe connection. 


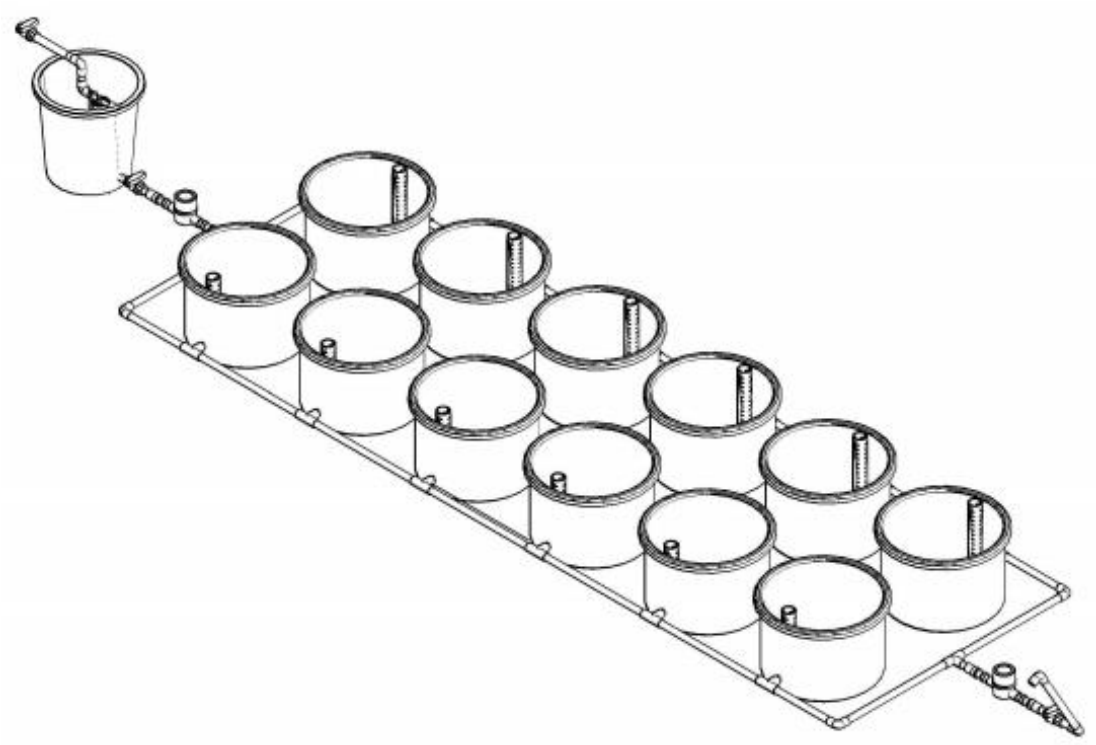

Figure 7: The fifth irrigation system design (D5)

Leaching is carried out at the 81 days after planting. It can also be done after harvesting the SRI season (preparation for the Salibu planting season). Water circulation in D5 has been running well with automatic. The availability of water is by the water needs (conditions of the average water content of $47 \%$ (conditions of field capacity $42.4 \%$ )). At the same time, the D6 experienced a lot of water flow resistance, especially in the pot with the outlet pipe (drain). This obstacle comes from the accumulation of fine soil particles (clay) carried by the water flow in the draining process (towards the pipe set). It is necessary to clean the outlet regularly to keep the water circulation running well.

In the design of the pots (D5 and D6), there is a biopore pipe installed perpendicular to the bottom plane of the pot. Then a layer of split stone is installed with a height of $10 \mathrm{~cm}$, filter cloth is installed, and then the planting media (a mixture of alluvial soil, sand and organic fertilizer (goat manure) are added). The perforated pipe functions so that water from the tub can enter the planting medium correctly by treating the water level (tub set). In addition, the biopore pipe also functions to assist the draining process when runoff flow occurs in the planting media pot so that it enters the water circulation and is drained towards the drainage pipe (pipe set). The size of the connecting pipe and the pipe set is in diameter. The distance of the connecting pipe between the pots is about $10 \mathrm{~cm}$. The upright pipe set is arranged so that when the datum is perpendicular to the optimal height, the water level in pot 1.

The pots on D5 are separated, while on D6, the pots are used as planting media pots. So that D6 experiences a lot of water flow resistance due to blockages in the pipes due to soil particles that accumulate in the waterways. This causes the growth of plants on D5 to be better than D6.

The D5 design is more appropriate to be used as a proper irrigation system for SRI Salibu paddy cultivation. This system can provide water needs with automatic water management and can provide water lost due to the process of evapotranspiration. The fifth design of the irrigation system was finally referred to as the subsurface evapotranspiration irrigation system, which was most appropriate for SRI and Salibu paddy. Although there were variations in the water level in each pot, the average water level in the pot was $8.6 \mathrm{~cm}$ from the bottom of the potting media.) 




Figure 8: The sixth irrigation system design (D6)

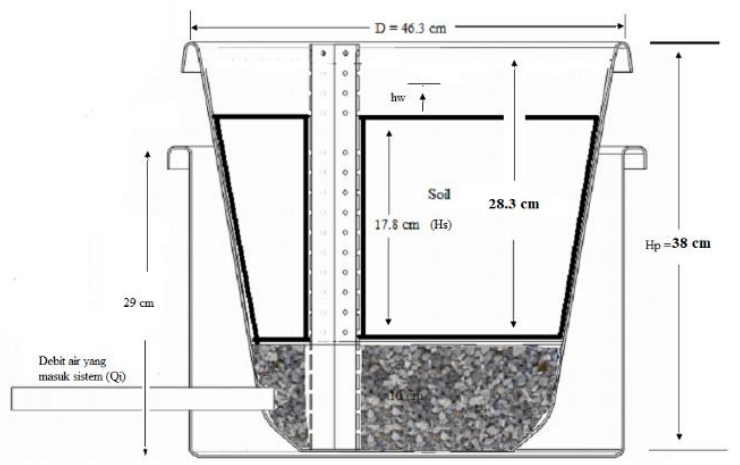

Figure 9: Arrangement of media in plant pots on the fifth pot design (D5) and (D6)

The best irrigation system (automatic), the most optimal harvest production, and water productivity is the fifth irrigation system design (Evapotranspiration irrigation system design) in the application of SRI Salibu cultivation. Evapotranspiration irrigation system design can produce multiple crops.

The growth of SRI paddy with evapotranspiration irrigation systems up to the age of 133 DAP (the first planting season (SRI paddy) is an average of $156 \mathrm{~cm}$, while at the age (134 to 248 DAP) (SRI Salibu paddy) the average height is $108 \mathrm{~cm}$. The maximum number of leaves produced from the growth of the vegetative phase up to the age of $130 \mathrm{DAP}$ was an average of 174 leaves, while the maximum number of leaves from the age of 134 to the age of 170 DAP was 98 leaves (second planting season). The productive yield of the evapotranspiration irrigation system in SRI Salibu paddy cultivation was 23 tillers with 23 productive tillers at 113 DAP. The crop coefficient ranged from 0.5 to 1.464 with an average of 1.020 (standard deviation of 0.091). This shows that the evapotranspiration irrigation system effectively provides water discharge that occurred during observation. This result is in line with previous research, the crop coefficient for SRI paddy with water management varied from 0.7 to 1.24 [3]. Meanwhile, the highest number of tillers in the Salibu paddy planting season was 16 productive tillers at 261 DAP. Salibu is still alive (24 July 2021) and is still producing productive tillers.

\section{CONCLUSIONS AND SUGGESTION}

The design of the evapotranspiration irrigation system (design 5) is the most optimal design for SRI Salibu paddy cultivation. SRI Salibu cultivation can increase paddy production with the support of an evapotranspiration irrigation system. This irrigation system can meet the water needs for the growth of SRI Salibu paddy. It can provide multiple paddy yields (more than two paddy harvests). This irrigation system is recommended for SRI Salibu paddy cultivation activities. 


\section{REFERENCES}

[1] Abdulrachman S, Suhartatik E, Erdiman, Susilawati, Zaini Z, Jamil A, Mejaya MJ, Sasmita P, Abdullah B, Suwarno B, et al. 2015. Panduan Teknologi Budidaya Padi Salibu

[2] Anas I, Uphoff N. 2009. Prospect of The System of Rice Intensification ( SRI ) in Asia. http://d.yimg.com/kq/groups/21477406/398766272/name/Iswandi+and+Uphoff+abstract+PROSPECT+OF+SY STE M+OF+RICE+INTENSIFICATION.doc.

[3] Arif C, Setiawan BI, Sofiyuddin HA, Martief LM, Mizoguchi M, Doi R. 2012. Estimating Crop Coefficient in Intermittent Irrigation Paddy Fields Using Excel Solver. Rice Sci. 19(2):143-152. doi:10.1016/S16726308(12)60033-X

[4] Bouman, B.A.M. and Tuong, T.P. 2001 Field Water Management to Save Water and Increase its Productivity in Irrigated Lowland Rice. Agricultural Water Management, 49, 11-30.

[5] Fitri R, Erdiman, Kusnadi N, Yamaoka K. 2019. SALIBU technology in Indonesia: an alternative for efficient use of agricultural resources to achieve sustainable food security. Paddy Water Environ. 17(3):403-410. doi:10.1007/s10333-019-00735-0.

[6] Fuadi, N. A., Purwanto, M. Y. J., \& Tarigan, S. D. (2016). Kajian kebutuhan air dan produktivitas air padi sawah dengan sistem pemberian air secara sri dan konvensional menggunakan irigasi pipa. Jurnal Irigasi, 11(1), 23-32.

[7] Hasanah NAI, Setiawan BI, Arif C, Widodo S. 2015. Evaluasi Koefisien Tanaman Padi Pada Berbagai Perlakuan Muka Air. J Irig. 10(2):57. doi:10.31028/ji.v10.i2.57-68.

[8] Nurrochmad, F. 2007. Analisis kinerja jaringan irigasi. agriTECH, 27(4).

[9] Pasaribu PO, Triadiati, Anas I. 2018. Rice ratooning using the salibu system and the system of rice intensification method influenced by physiological traits. Pertanika J Trop Agric Sci. 41(2):637-654.

[10] Subagio H. 2019. Evaluasi Penerapan Teknologi Intensifikasi Budidaya Padi di Lahan Rawa Pasang Surut. J Pangan. 28(2):95-108. doi:10.33964/jp.v28i2.438.

[11] Subagyono K, Dariah A, Surmaini E, Kurnia U. 2004. Pengelolaan air pada tanah sawah. Tanah Sawah dan Teknol Pengelolaannya., siap terbit.

[12] Subari S, Joubert MD, Sofiyuddin HA, Triyono J. 2012. Pengaruh Perlakuan Pemberian Air Irigasi pada Budidaya SRI, PTT dan Konvensional terhadap Produktivitas Air. J Irig. 7(1):28. doi:10.31028/ji.v7.i1.28-42.

[13] Uphoff N, Fasoula V, Iswandi A, Kassam A, Thakur AK. 2015. Improving the phenotypic expression of rice genotypes: Rethinking "intensification" for production systems and selection practices for rice breeding. Crop J. 3(3):174-189. doi:10.1016/j.cj.2015.04.001.

[14] Wardana P, Widyantoro, Rahmini, Abdulrachman S, Zaini Z, Jamil A, Mejaya MJ, Sasmita P, Suwarno, Suhartatik E, et al. 2015. Panduan Teknologi Budidaya Padi SRI (System of Rice Intensification. 